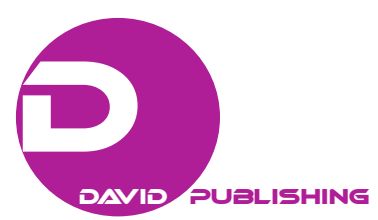

\title{
3rd Definition of SHRM: HR Systems Approach ${ }^{1}$
}

\author{
Gurhan Uysal \\ Ondokuz Mayis University, Samsun, Turkey
}

\begin{abstract}
First definition of SHRM is made by Devanna, Tichy and Fonbrum (1981, 1984). It is Michigan model. 1st definition relates HRM with strategic management. i.e., HRM affects firm-level strategies. Second definition is made by Wright and McMahan (1992). It relates HRM with performance. There exists direct relations between HRM and firm performance. Innovation capability of human resources provides of linear relation between HR and performance. HR make innovations, and it increases firm performance. This is linear relations in American HRM $($ HR (innovation) $\rightarrow$ performance). This study makes 3rd definition in SHRM. It relates performance with HR systems. Accordingly, HR applies HR systems in organizations that increases employee's individual performance. and individual performance has impact on firm performance. In 3rd definition there is relation between HR system and performance through individual performance. Moderator is individual performance.
\end{abstract}

Keywords: SHRM, 3rd definition, HR systems, individual performance, firm performance

\section{Introduction}

Personnel Management (PM) appeared with neoclassical management theory in 1930s. First PM departments founded during 1930s. Human Resources Management (HRM) appeared in 1960s and 1970s due to intense competition in global economy. Firms are practicing PM and HRM. Strategic Human Resources Management (SHRM) posesses only theoreticak phase currently.

Between 1980 and 2000, theoretical base of HRM is developed, and firms started to organize HRM department in 2000s. SHRM has only theoretical base, i.e., firms do not apply SHRM in organizations. However, Henkel appointed Global HR Director in to Board of Directors. Sylvie Nicol would effect human-related decisions at top-level. That appointment might mean that firms gradually started to apply SHRM in their organizational structure, because one definition of SHRM is that HR executives affect human-related decisions at top management.

HRM possesses theoretical development phase between 1980-2000. SHRM is facing same process todays between 2000-2020. Academics and practitioners argue theory of SHRM and firms apply SHRM near future. In addition, big companies started to apply SHRM in their organizations, i.e., HRM started to be involved with firm objectives, and HR executives effect decisions at the top level. Khawaja, Azhar, and Arshad (2014) define SHRM as achievement of organizational goals through human resources.

PM is technical and processing HR-related practices such as staffing, training, wage, performance evaluations, others. HRM is strategic. HRM implements both technical and strategic practices. HRM applies

Gurhan Uysal, Ph.D. / Management, associate professor, School of Business, Ondokuz Mayis University, Samsun, Turkey.

Correspondence concerning this article should be addressed to Gurhan Uysal, Ondokuz Mayıs University, School of Business, 3rd floor, Kurupelit Campus, 55139 Atakum-Samsun, Turkey.

${ }^{1}$ Participation: 6th ASOS Congress, 18-20 April, 2019, Alanya Alaaddin Keykubat University, Antalya, Turkey. 
HRM practices and affects human capital decisions at the top. Further, SHRM contains strategy concept; HRM has resources concept. Strategy is associated with HRM systems (Kazmi \& Ahmad, 2001). HRM becomes strategic when it is associated with corporate strategy and objectives. Firm management is to create fit between HRM and strategy. For example, Khawaja et al. (2014) suggest organizations to achieve goodness of fit between SHRM and firm's strategies.

HRM is functional, and SHRM is strategic and it involves with business strategies. HRM is to improve individual performance in organizations, and SHRM is related with organizational performance. SHRM emerges when HR strategies fit with business strategies (Kazmi \& Ahmad, 2001). SHRM is explained with HR strategies, i.e., relationship between HR strategies and firm strategies. SHRM related with best-fit model, strategic partner concept, and resource-beased view (Blackman, O'Flynn, \& Mishra, 2010, p. 237). For SHRM, employees are human capital to which this notion is explored widely in 2000s.

\section{3rd Definition}

There are two definitions of strategic human resource management, so far yet (SHRM). This study makes third definition. Devanna, Tichy, and Fombrun (1981) identify HRM with strategic management, the role of HRM in achievement and implementation of strategic management. Role of HRM is strategic fit. HRM strategies contribute to firm strategies. Fit approach is key to first definiton. HR strategies are to fit with firm's strategies. It is external fit (Delery \& Doty, 1996). It is first definition of SHRM. HRM involves with business strategies. First definition is related with strategic fit and strategic partner. Strategic partner is that HR conributes to development of firm strategies.

Employees are resources in HRM. Resources create competitive advantage, according to Barney (1991). Resources are distinctive and enable firm to implement differentiation strategy. Wright and McMahan (1992) made 2nd definition of SHRM. Wright and McMahan relates HRM with firm performance. Devanna et al. (1981) relate HRM with strategic management, and Wright and McMahan relate HRM with firm performance. 1990s witnessed black box discussion in SHRM. Proposal is that, individual performance might be black box variable between HRM and firm performance. This study makes 3rd definition of SHRM. It relates strategic HRM with HR system. Firms implement HR system (or HR bundles) in HRM department to achieve higher individual performance. Therefore, SHRM is defined as implementing HR system in organizations to increase individual performance. Aim is again firm performance. Finally, in global economy, firms do not have SHRM departments in organizations. Firms possess personnel management and HRM departments. PM operates in HRM department. Firms are to establish strategic HRM department in order to apply SHRM in organization. Job definition of SHRM department is to apply HR system for individual performance, and apply HPWS (High Performance Work Systems) for performance.

This study intends to system approach in strategic HRM. HR systems have an impact on individual performance than individual HRM practices. New form of SHRM might be HR systems and HPWS. Focus of HRM is performance improvement, and it assumes that HR systems effectively have an impact on employee performance.

This study suggests a SHRM model, which covers HR systems (HR bundles), individual performance, and firm performance. Individuals carry out all tasks in organizations. Individual performance increases task performance and department performance. Employees work for organizational departments. Thus, tasks and department performance heightene firm performance. 
This study adopts universalistic approach between HRM and firm performance, which is based on best HRM practices, HPWSs, and linear relations (Delery \& Doty, 1996). Bayraktaroglu and Atay (2016) defend that universalistic approach assumes, HR systems have positive impact on organizational performance. So, HR systems impact firm performance via employee job performance.

Accordingly, Venkataiah (2014) finds that HRM practices (= compensation, promotion, performance evaluation) enhance employee performance.

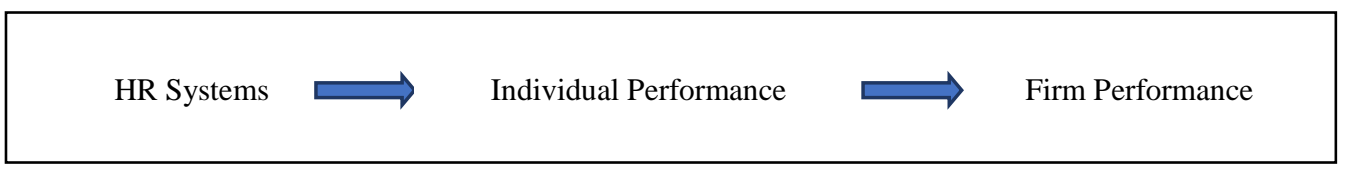

Figure 1. 1st model of SHRM.

Successful apply of SHRM in organizations depends on that HR managers must have system approach in HRM for performance, i.e., HR managers use performance management, career management, talent management, interrelated HRM practices as systems in HRM. For interrelated HRM practices, firm needs internal fit (Delery \& Doty, 1996). External fit is necessary between HR strategy and firm strategy alignment. Therefore, internal fit is effective for 3rd definition of SHRM, and external fit is necessary for 1st definition of Devanna et al. (1981). HR bundles represent interrelationships between HRM practices. For example, for career management, HR is to apply training, performance evaluations, career planning, reward policy, and compensation together for star employees. Therefore, bundle of career planning, performance evaluation, training and compensation create HR system for employee performance. However, HRM applies individual and separates HRM practices onto employees. HR systems and SHRM apply HRM practices interrelated and bundles.

It assumes that American HRM adopts system approach in HRM, HR system. For example, Huselid (1995) advocates system approach and HPWS in HRM. Moreover, Uysal (2012) finds interrelationships between HRM practices. Again, Harvard Model in HRM is based on HR systems-firm performance relationship (Özutku, 2010).

\section{HR Systems}

HRM systems aim to increase job performance with HPWSs, because human resources (= employees) have effect on firm performance through job performance. HRM systems are associated with firm strategies and job performance. HR develops and implements firm strategies. Therefore, performance of employees is crucial to achieve firm's objectives. For example, Harvard Model in HRM is associated with relations between HRM systems and firm performance. Armstrong (2017) (trs. Gürol \& Gemici, 2017), defines HRM systems with interrelated HRM practices. By this sense, performance management, career management, talent management are practicing HRM systems. In addition, MacDuffie (1996) identifies HR systems with HR bundle. Further, Uysal (2012) finds positive correlations between HRM practices, i.e., between staffing, training, performance evaluations, reward.

Susilowat, Hutagaol, Pasaribu, and Djohar (2012) suggest that HRM systems may become black box between SHRM and firm performance. They claim, black box between SHRM and firm performance is not clarified yet. This study proposes job performance and HR systems as a black box mediator between SHRM and firm performance. Because HR systems improve competency, motivation, and performance of employees. 
For example, performance management is part of HR systems, and it contains bundling of HRM practices as interrelated. Performance management is apply of interrelated HRM practices such as performance appraisal, training, compensation, and careers. Khawaja et al. (2014) claim that HR system influences management of HR in organizations in such that level of competence, workforce skills, engagement and commitment.

Kazmi and Ahmad (2001) claim that HRM systems drive strategic objectives of firm. Therefore, HRM systems are related with SHRM and firm performance. Kazmi and Ahmad (2001) relate HR systems with SHRM with notion that HRM systems are required to formulate and implement business strategies.

HPWSs are identified by Huselid and Becker, 1997, as internally consistent and coherent HRM systems, which improve employees' competency (Jalloh \& Jalloh, 2016, p. 89). HPWS concept is implemented in USA in 1990s. HPWSs promote employee skills, individual performance, and commitment.

For example, performance management is sample of HR system practices. It includes interrelated HRM practices: interrelations among coaching, training, performance assessment, compensation and career planning. In order to apply HR system or performance management system, HR managers must have system thinking for HR practices. HR managers apply HR bundles for employees. HR bundle would increase performance improvement of employees.

\section{SHRM: Firm Performance Framework}

HRM has resource concept. Tie between resource and strategy may be achieved through organizational objectives, i.e., performance of resources enables firm to achieve objectives. There may be three links in SHRM: resources approach, strategy, and objective. HRM is functional, and possesses functional strategies; top management has business level strategies. SHRM is that functional strategies enable firm to reach business strategies. Thus, HRM is involved with human capital-related decisions at top level. Jalloh and Jalloh (2016) view that SHRM is to increase firm performance through people. In aspect of people, job performance is crucial. HRM contributes to firm and employees. How does HRM success that goal? HR Journal (2019) replies that HRM may contribute to employees and firm objectives through career, career management such as by preparing career maps.

Jalloh and Jallod (2016) consider employee performance with SHRM perspective. Human resources like others affect competitive advantage of firm. HRM field appeared thorugh 1970s due to intense competition. According to Ugheoke, Isa, and Noor (2014), SHRM has a significant positive influence on tangible performance in Nigerian firms. Their study recommends that implementing SHRM practices within SMEs induces firms performing better.

SHRM might be related with competency and job performance, because job performance of employees may increase firm performance and competency increases job performance. Therefore, alternative model of SHRM is:

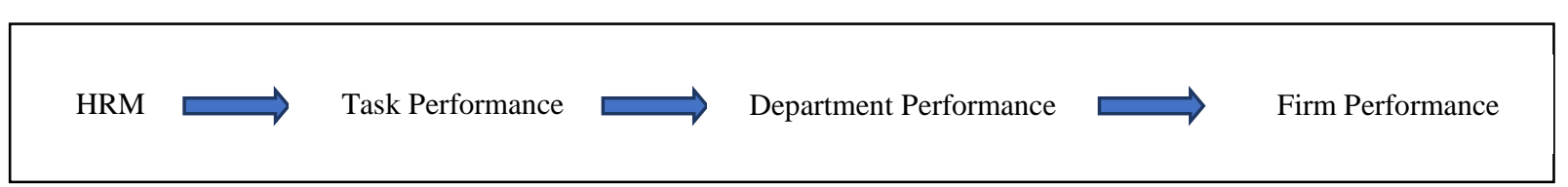

Figure 2. 2nd SHRM model.

According to this HRM model, HRM practices increase task performance of employees; task performance affects department performance; and all departments performance increases firm performance. 
This linear relations symbolizes that HRM is to focus on increasing competency of employees and job performance and so, job performance would have impact on firm performance. Therefore, HRM focuses on employee development, because moderator between HR and firm performance is employees.

\section{ROI and OBs}

In this study, SHRM is related with HR systems. Further, this study relates strategic HR with finance theory. Return on Investment (ROI) makes HRM have impact on financial performance. HRM may affect firm performance through HR investments. ROI of HR might be Organizational Behaviours (OBs). Many studies prove that HRM results in OBs. HRM means investing people. Thus, ROI of HR might be organizational behaviours. Application of HR develops positive organizational behaviours on employees, such as citizenship behaviours, commitment, satisfaction, organizational justice, etc.; OBs affect firm performance via human capital's attitude and behaviours. Human capital is related with job performance, including knowledge, skills, and experience of employees. Human capitals work for critical positions in organizations.

SHRM is relation between HRM and firm objectives. HRM is interested with employee performance. When it is involved with firm objectives, it is defined as SHRM. Consequently, HRM may affect organizational performance via OBs, because practicing HRM in organization results in developing various OBs, such as organizational commitment, justice, citizenship behaviours, engagement, etc., and OBs affect employee performance.

Therefore, 3rd definition of SHRM includes HR system and OBs. For example, Huselid (1995) explores impact of ROI on financial performance of firm. Thus, ROI might be considered as a factor affecting firm's financial performance. According to Tüzüner (2018), ROI concept may be applied for financial and nonfinancial results. Employment relations, for example, are nonfinancial indicators.

How does HRM contribute to firm performance? Literature studies discuss that argument. HRM may contribue to firm performance via Obs, because OBs affect employee performance and employee performance has impact on firm performance through OBs. Outcomes of HRM are organizational behaviours. OBs develop effective job performance. Therefore, measurement effect of HRM is associated with OBs.

Finally, Welch (2019) suggests that firms develop ROI for HRM. Instead, this study proposes OBs as ROI of HRM. OBs affect job performance of employees and so, organizational performance.

\section{Conclusion}

Human resources of company are qualified as assets, resources, and capital. Human resources are human asset, human resources, and human capital that make company achieve business objectives.

\section{References}

Akdemir, B. (2017). Strategic human resource management. Istanbul: Beta Publishing.

Barney, J. (1991). Firm resources and sustained competitive advantage. Journal of Management, 17(1), 99-120.

Bayraktaroğlu, S., \& Atay, E. (2016). Strategic human resource management. Istanbul: Beta Publishing.

Blackman, D., O'Flynn, J., \& Mishra, D. P. (2010). Can strategic human resource management enable gross national happiness? International Journal of Commerce and Management, 20(3), 232-245.

Delery, J. E., \& Doty, H. D. (1996). Modes of theorizing strategic human resource management: Tests of universalistic, contingency and configurational predictions. Academy of Management Journal, 39(4), 802-835.

Delery, J. E. (1998). Issues of fit in strategic human resource management: Implications for research. Human Resource Management Review, 8(3), 289-308. 
Devanna, M. A. \& Fombrun, C., \& Tichy, N. (1981). Human resources management: A strategic perspective. Organizational Dynamics, 9, 51-57.

Gürol, Y. D., \& Gemici, E. (2017). Armstrong's strategic human resource management handbook. Ankara: Nobel Publishing.

Huselid, M. A. (1995). The impact of human resource management practices on turnover, productivity and corporate financial performance. Academy of Management Journal, 38(3), 635-672.

Huselid, M. A., \& Becker, B. (1997). The impact of higher performance work systems, 1mplementation effectiveness and alignment with strategy on shareholder wealth. Working Paper.

Jalloh, A. A., \& Jalloh, A. U. (December 2016). The effects of motivation on employee performance: A strategic human resource management. International Journal of Management Sciences and Business Research, 5(12), 81-96.

Kazmi, A., \& Ahmad, F. (May-August 2001). Differening approaches to strategic human resource management. Journal of Management Research, 1(3), 133-140.

Keçecioğlu, T. (2017). Strategic human resource management. Kocaeli: Umuttepe Publishing.

Khawaja, K. J., Azhar, S., \& Arshad, A. (2014). Examining strategic human resource management and organizational effectiveness in Pakistani organizations. International Journal of Human Resource Studies, 4(3), 214-227.

Özutku, H. (2010). Human resources management and organizational performance. Gazi Publishing, Ankara.

SHRM White Paper. (2019). Bir İK'c1 Kolay Yetişmiyor! HR Dergi, Mart, 52-53.

Susilowati, Y., Hutagaol, P., Pasaribu, B., \& Djohar, S. (2012). The effectiveness of strategic human resource management in increasing firm performance in Indonesia. Proceedings of World Business and Economics Research Conference, November.

Tüzüner, L. (2018). Measurements in human resources management practices. Istanbul: Beta Publishing.

Ugheoke, S. O., Isa, M. F. M., \& Noor, W. S. W. (2014). Assessing the 1mpact of strategic human resource management on tangible performance: Evidence from Nigerian SMEs. International Review of Management and Business Research, 3(2), 1163-1173.

Uysal, G. (2012). For the development of effective HRM systems: Inter-relationships between HRM practices using correlation analysis. World Review of Entrepreneurship, Management and Sustainable Development, 8(1), 1-12.

Venkataiah, C. (2014). Impact of strategic human resource management practices on employee performance. Research Journal of Social Science \& Management, 4(8), 62-68.

Welch, J. (2019). Thoughts about AHRM departments. Capital, 27(4), 198-199.

Wright, P. M. \& McMahan, G. C. (1992). Theoretical perspectives for strategic human resource management. Journal of Management, 18(2). 295-320. 